\title{
FAKTOR YANG MEMPENGARUHI KEPUTUSAN MAHASISWA S1 EKONOMI ISLAM FAKULTAS EKONOMI DAN BISNIS UNIVERSITAS AIRLANGGA BELUM MENJADI NASABAH BANK SYARIAH
}

\author{
Mega Nilasari Johan \\ Mahasiswa Program Studi S1 Ekonomi Islam - Fakultas Ekonomi dan Bisnis - Universitas \\ Airlangga \\ Email: nilajohan.nj@gmail.com
}

Ririn Tri Ratnasari

Departemen Ekonomi Islam - Fakultas Ekonomi dan Bisnis - Universitas Airlannga

Email: ri.ratnasari@gmail.com

\begin{abstract}
:
This research aims to determine the factors that influence the decision of Students of Islamic Economics FEB UNAIR not selected as Syariah Bank's Customer.

This research used quantitative methods through exploratory factor analysis. Characteristic of the research population are students of Islamic Economics UNAIR who following the active class. The number of samples in pre eliminary test by conducting a written interview by 25 respondents, and main test required 100 respondents. The sampling technique used is probability sampling. Sampling was done using simple random sampling.

Based on the results of the study indicate that there are four factors that affect the decision of Students of Islamic Economics FEB UNAIR. The four factors as a result of reduction of processing factor analysis. These four factors named by factor of the brand image, product knowledge, spurious loyalty, service experience.

Advice for the Syariah Bank are improves service experience for every remittance transactions by ontime, Syariah Bank offers interesting sales promotion to get customers, more socialization about negative impact of riba, not burden charge for every transactions in ATM or online banking. Advice for the next researcher, can analys factors made from this research influencing other variabel that decision muslim students SI FEB UNAIR have not been Syariah Bank's customer yet, for the second next research, make the factors in this research being exogen variables that influenced muslim consumen behavior to syariah Bank.
\end{abstract}

Keyword: student decision, Syariah Bank, brand image, product knowledge, spurious loyalty, service experience

\section{PENDAHULUAN}

\section{A. Latar Belakang Masalah}

Sebagai Negara dengan kuantitas penduduk muslim terbesar di dunia, institusi perbankan di Indonesia dituntut untuk dapat mengoperasionalkan sistem perbankan yang berbasiskan kepada syariat Islam. Alamsyah (2012:4) menjelaskan bahwa, meskipun agak terlambat, setelah beberapa dekade diambangkan oleh kaum ulama dan pemerintah tentang persoalan halal dan haramnya bunga dalam perbankan tahun 1992 dikeluarkan UU No. 7 Tahun 1992 tentang perbankan yang merupakan tonggak legalitas diadopsinya perbankan syariah dalam sistem perbankan di Indonesia. Sampai saat ini, perkembangan perbankan syariah sangat pesat baik dari segi jumlah usaha, kantor, 
unit, penghimpunan dan pembiayaan, maupun ragam produknya. Perkembangan peran perbankan syariah di Indonesia tidak terlepas dari sistem perbankan di Indonesia secara umum.Sistem perbankan diatur dalam UU.No 10 tahun 1998 dimana bank umum adalah bank yang melaksanakan kegiatan usaha secara konvensional atau dengan prinsip syariah yang kegiatannya memberikan jasa dalam lalu lintas pembayaran. Peran Bank Syariah dalam memacu pertumbuhan perekonomian daerah semakin strategis dalam rangka mewujudkan struktur perekonomian yang semakin berimbang. Dukungan terhadap pengembangan perbankan syariah juga diperlihatkan dengan adanya "dual banking system", artinya bank konvensional diperkenankan untuk membuka unit usaha perbankan syariah (Ratnawaty dkk., 2008:5).

Penelitian ini akan dilakukan di Fakultas Ekonomi dan Bisnis Universitas Airlangga dengan objek penelitian mahasiswa Ekonomi Islam. Alasan peneliti memilih mahasiswa Ekonomi Islam sebagai subyek penelitian karena mahasiswa Ekonomi Islam merupakan mahasiswa yang memiliki cukup pengetahuan mengenai kegiatan perekonomian yang berbasis Islami yang sesuai dengan ajaran al-Quran dan Hadist, dan mengetahui beberapa unsurunsur yang tidak diperbolehkan Islam dalam aktivitas perekonomian tersebut seperti gharar, maysir, riba.

\section{B. Rumusan Masalah}

Perumusan masalah dalam penelitian ini faktor apa saja yang mempengaruhi keputusan mahasiswa $\mathrm{S} 1$ Ekonomi Islam Fakultas Ekonomi dan Bisnis Universitas Airlangga belum menjadi nasabah Bank Syariah?

\section{Tujuan Penelitian}

Tujuan dari penelitian ini adalah untuk mengetahui faktor-faktor yang mempengaruhi keputusan mahasiswa $\mathrm{S} 1$ Ekonomi Islam Fakultas Ekonomi dan Bisnis Universitas Airlangga belum menjadi nasabah Bank Syariah.

\section{LANDASAN TEORI}

\section{A. Definisi Pemasaran Islam}

Nilai utama yang dibawa oleh sebuah organisasi Islam dalam setiap aktivitasnya adalah ketauhidan.Hal ini memiliki makna pengakuan bahwa Allah SWT.adalah Tuhan dari segala sesuatu, pencipta dan penguasa dari segala kehidupan, serta Dia-lah yang berhak diibadahi juga disifati dengan sifat-sifat yang Maha Sempurna (Ratnasari, 2012:33).

\section{B. Perilaku Konsumen Muslim}

Setiadi (2008:2) menjelaskan perilaku konsumen adalah tindakan yang langsung terlibat dalam mendapatkan, mengkonsumsi, dan menghabiskan produk atau jasa termasuk proses keputusan yang mendahului dan menyusuli tindakan ini. Perilaku konsumen bersifat dinamis, berarti bahwa perilaku konsumen bergerak sepanjang waktu 
dalam perekembangan strategi pemasaran.

Dalam perspektif ekonomi Islam, perilaku konsumsi seorang muslim didasarkan pada beberapa asumsi sebagaimana dikemukakan oleh Kahf (1999:70), yaitu :

1. Islam merupakan suatu agama yang diterapkan di tengah masyarakat.

2. Zakat hukumnya wajib.

3. Tidak ada riba dalam masyarakat.

4. Prinsip mudharabah diterapkan dalam aktivitas bisnis.

5. Konsumen berperilaku rasional yaitu berusaha mengoptimalkan pemenuhan kebutuhan pokok.

Faktor yang Mempengaruhi Keputusan:

1. Faktor Strategi Pemasaran

$$
\text { Zeithaml (2000: }
$$

mengemukakan konsep bauran pemasaran tradisional terdiri dari $4 \mathrm{P}$ yaitu product, price, place, promotion.Sementara itu, untuk pemasaran jasa perlu diperluas dengan penambahan unsur non-traditional marketing mix, yaitu people, physical evidence, process, sehingga menjadi 7P. Masing-masing dari tujuh unsur bauran pemasaran tersebut saling berhubungan dan tegantung satu sama lainnya dan mempunyai suatu bauran yang optimal sesuai dengan karakteristik segmennya.

2. Faktor Lingkungan Sosial

$$
\text { Kottler dan Keller (2009:166) }
$$
menjelaskan bahwa, faktor lingkungan merupakan faktor eksternal yang mempengaruhi keputusan konsumen dalam pembelian suatu produk, faktorfaktor tersebut meliputi:

a. Kebudayaan (culture).

b. Sub Budaya (subculture).

c. Kelompok Tatap Muka (face to face group).

\section{Faktor Individu}

$$
\text { Assael (1998:84) menjelaskan }
$$

bahwa, faktor individu didefinisikan sebagai karakteristik psikologis seseorang yang berbeda dengan orang lain yang menyebabkan tanggapan yang relatif konsisten dan bertahan lama terhadap lingkungan.

4. Kualitas Jasa dalam Perspektif Islam Ratnasari (2012) dalam Measuring Customer Service Quality Based on Fatanah Implementation menjelaskan bahwa, Islam merupakan agama yang mengatur segala dimensi kehidupan. AlQuran diturunkan Allah SWT kepada manusia untuk memberikan solusi atas segala permasalahan hidup.Othman dan Owen (2001) telah memperkenalkan enam dimensi untuk mengukur kualitas jasa pada lembaga keungan syariah. Metode ini menggunakan lima dimensi yang terdapat pada SERVQUAL dan menambahkan dimensi compliance/kepatuhan (kepatuhan terhadap syariat islam) di dalamnya keenam dimensi tersebut dikenal dengan CARTER model yakni, Compliance, Assurance, Reliability, Tangible, Empathy, dan Responsiveness (CARTER).

5. Store Atmosphere Perspektif Islam 
Gilbert (2003:129) menyebutkan bahwa terdapat beberapa faktor atmosfir yang islami pada sebuah toko yaitu, faktor desain terdiri dari: desain tertutup, terdapat pemisah antara kaum laki-laki dan non-muslim, desain interior dan juga eksterioryang menarik, serta tata letak berbeda untuk setiap sudut ruangan. Gilbert (2003:130) menyebutkan faktor lainnya yaitu faktor suasana, terdiri dari: pencahayaan yang cukup, ruangan perawatan yang wangi, suhu ruangan yang sejuk, dan terdapat musik islami yang dapat menyejukkan konsumen yang datang.

\section{Bank Syariah}

Perbankan syariah atau Perbankan Islam adalah suatu sistem perbankan yang dikembangkan berdasarkan syariah (hukum) Islam. Usaha pembentukan sistem ini didasari oleh larangan dalam agama Islam untuk memungut maupun meminjam dengan bunga atau yang disebut dengan riba serta larangan investasi untuk usahausaha yang dikategorikan haram (misal: usaha yang berkaitan dengan produksi makanan atau minuman haram, usaha media yang tidak Islami dll), dimana hal ini tidak dapat dijamin oleh sistem perbankan konvensional (PKES, 2008:8).

\section{Hukum Bunga}

Praktek pembungaan uang saat ini telah memenuhi kriteria riba yang terjadi pasca zaman Rasulullah Saw., yakni riba nasi'ah.Dengan demikian, praktek pembungaan uang ini termasuk salah satu bentuk riba, dan riba haram hukumnya.Pengaruh "riba" dalam kestabilan ekonomi sebuah Negara telah lama menjadi kajian para ahli.Sebaliknya, tatanan dalam Islam adalah keseimbangan yang adil.Islam juga bersikap di tengah-tengah antara iman dan kekuasaan (Wibowo dan Widodo, 2005:2).

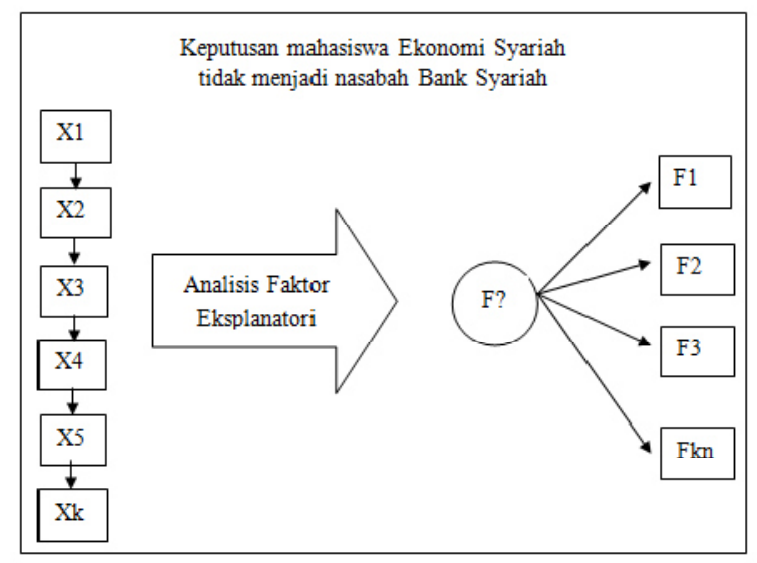

Sumber: Solimun. Multivariate Analysis Structural Equation Modelling (SEM )Lisrel dan Amos. Halaman 63 (diolah).

\section{Gambar 1. MODEL ANALISIS}

\section{METODE PENELITIAN}

\section{A. Pendekatan Penelitian}

Penelitian ini menggunakan pendekatan kuantitatif eksploratori (eksploratif).Malhotra (2009:89-90) mengatakan bahwa riset eksploratif bertujuan untuk mendapatkan gambaran dan pemahaman mengenai masalah yang dihadapi peneliti.

\section{B. Identifikasi Variabel}

Dalam penelitian yang menggunakan analisis faktor, tidak diidentifikasikan variabel bebas maupun variabel terikat. Pada penelitian ini dirumuskan 20 indikator yang akan 
direduksi menjadi faktor atau variabel. Variabel yang akan diteliti adalah keputusan mahasiswa S1 Ekonomi Islam Fakultas Ekonomi dan Bisnis Universitas Airlangga tidak menjadi nasabah Bank Syariah di Surabaya.

\section{Definisi Operasional Variabel}

Berdasarkan wawancara tertulis tersebut diperoleh indikator-indikator keputusan mahasiswa S1 Ekonomi Islam Fakultas Ekonomi dan Bisnis Universitas Airlangga belum menjadi nasabah Bank Syariah di Surabaya sebagai berikut :

1. Jumlah ATM Bank Syariah yang tersebar masih sedikit dan sulit dijangkau (X1) adalah fasilitas mesin ATM yang diberikan oleh Bank Syariah masih kurang memadai dan masih terbatas jumlahnya di berbagai wilayah sehingga sulit untuk dijangkau konsumen.

2. Kantor cabang bank syariah masih sedikit sehingga untuk menjangkaunya sulit/jauh dari tempat tinggal (X2) adalah cabang unit Bank Syariah yang tersebar masih sedikit sehingga untuk menjangkaunya masih sulit dari tempat tinggal.

3. Merasa sudah puas menjadi nasabah bank konvensional sehingga tidak perlu menjadi nasabah bank syariah (X3) adalah konsumen bank konvensional sudah puas dengan kualitas bank konvensional sehingga tidak perlu lagi membuka rekening baru di Bank Syariah.
4. Adanya anggapan bahwa, jika bunga tidak melebihi tingkat inflasi $10 \%$ maka bunga bank tidak disebut riba (X4) adalah konsumen menganggap bahwa bunga tidak menjadi riba selama tingkat bunga tidak melebihi $10 \%$ dari tingkat inflasi.

5. Membuka rekening baru lagi di bank syariah maka beban biaya administrasi perbulan bertambah karena sudah memiliki rekening di bank konvensional (X5) adalah konsumen merasa terbebani dengan biaya administrasi perbulan jika konsumen membuka rekening baru lagi di Bank Syariah karena sebelumnya sudah memiliki rekening bank konvensional.

6. Lokasi bank jauh dijangkau dari kampus (X6) adalah lokasi Bank Syariah jauh dijangkau dari tempat tinggal mahasiswa.

7. Kebutuhan untuk transaksi jual-beli online menggunakan rekening bank konvensional karena sebagian besar customer/seller juga menggunakan rekening bank konvensional (X7) adalah mahasiswa yang memiliki bisnis online menyesuaikan dengan sebagian besar rekening pembelinya sehingga tidak dikenakan potongan biaya transaksi.

8. Keluarga juga menjadi nasabah bank konvensional, sehingga lebih hemat karena tidak dikenakan biaya potongan ATM lain (X8) adalah konsumen mengikuti keluarga karena lebih mudah untuk bertransaksi seperti 
mentransfer uang untuk kebutuhan pembayaran SOP.

9. Anggapan bahwa Bank Syariah kurang bonafit (X9) adalah konsumenmenganggap Bank Syariah kurang memiliki value jika dibandingkan bank konvensional.

10. Kurang mendapatkan informasi dengan jelas tentang produk-produk Bank Syariah (X10) adalah konsumen kurang mengetahui informasi tentang sistem dan produk-produk yang ditawarkan Bank Syariah.

11.Promosi penjualan (bonus) yang ditawarkan Bank Syariah kurang menarik bagi calon nasabah (X11) adalah konsumen kurang tertarik dengan Bank Syariah karena promosi penjualan dengan pemberian bonus yang kurang menarik.

12.Keuntungan bagi hasil Bank Syariah dianggap kurang menguntungkan dibandingkan bunga bank konvensional (X12) adalah keuntungan bagi hasil yang diberikan Bank Syariah kurang menguntungkan dibandingkan keuntungan yang diperoleh dari bank konvensional.

13.Merasa kurang leluasa (gap) dalam berinteraksi di bank karena image Bank Syariah sebagai tempat orang-orang fanatik (X13) adalah konsumen merasa kurang leluasa berinteraksi di dalamnya karena suasana Bank Syariah yang sangat kental dengan suasana Islami.
14.Terpaksa membuka rekening bank konvensional karena suatu kebutuhan yang mengharuskan memiliki rekening bank konvensional (X14) adalah konsumen yang diharuskan memiliki rekening bank konvensional karena kebutuhan pekerjaan atau kebutuhan beasiswa.

15.Pernah berpengalaman mendapatkan pelayanan di Bank Syariah tetapi kurang memuaskan (X15) adalah pernah berpengalaman mendapatkan pelayanan dari Bank Syariah tidak memuaskan seperti kebutuhan mengirimkan vang kepada saudara/oranglain yang merupakan pengguna rekening Bank Syariah.

16.Istilah produk pada layanan perbankan di Bank Syariah dengan nama Islami sehingga konsumen sulit untuk memahami (X16) adalah sebagian konsumen masih tidak memahami produk-produk Bank Syariah dengan nama-nama arab seperti mudharabah, murabahah, musyarakah, ijarah, wadiah dan lainlain.

17.Anggapan bahwa sistem bagi hasil yang diberikan oleh Bank Syariah secara bisnis sama dengan bunga bank konvensional (X17) adalah konsumen menganggap bahwa bagi hasil merupakan istilah lain Bank Syariah yang memiliki makna sama dari bunga yang diberikan bank konvensional. 
18.Bank syariah tidak menjanjikan keuntungan yang pasti dalam produk perbankan syariah kepada calon nasabah (X18) adalah nasabah beranggapan bahwa keuntungan yangdidapatkan dari Bank Syariah nilainya tidak pasti dalam produk layanan perbankan syariah.

19. Bank Syariah tidak menawarkan keuntungan diskon belanja pada storestore di pusat perbelanjaan (X19) adalah Bank Syariah belum menawarkan keuntungan berupa diskon belanja di pusat-pusat perbelanjaan.

20. Produk pada layanan perbankan syariah masih kurang variatif untuk memenuhi kebutuhan calon nasabah (X20) adalah calon nasabah menilai produk layanan perbankan syariah yang ditawarkan tidak variatif seperti yang ada pada bank konvensional.

\section{Variabel-variabel}

tersebut

kemudian akan diteliti lebih lanjut dengan cara menyebarkan kuesioner atau angket kepada responden terpilih, yang selanjutnya jawaban para responden akan diolah dengan menggunakan skala Likert yang terdiri dari, Sangat Setuju (skor 4), Setuju (skor 3), Tidak Setuju (skor 2), Sangat Tidak Setuju (1).

\section{Populasi Sampel}

Karakteristik populasi dalam penelitian ini adalah mahasiswa S1 Program Studi Ekonomi Islam Fakultas Ekonomi dan Bisnis Universitas Airlangga yang belum menjadi nasabah Bank
Syariah angkatan 2008 sampai 2013.Penelitian membutuhkan sebanyak 100 responden sebagai main test, yang didapat dari jumlah indikator 20 dikali dengan 5. Sampel penelitian ini yaitu konsumen mahasiswa Ekonomi Islam Universitas Airlangga.Hal tersebut sudah memenuhi jumlah sampel yang dianjurkan yaitu 50 sampai 100 sampel (Santoso, 2010:58).

\section{E. Metode Pengambilan Sampel}

Teknik pengambilan sampel yang digunakan adalah probability sampling yaitu teknik pengambilan sampel yang memberikan peluang yang sama bagi setiap unsur (anggota) populasi untuk dipilih menjadi anggota sampel (Anshori dan Iswati, 2009:102). Sedangkan dalam penentuan sampel menggunakan metode simple random sampling, dikatakan simple (sederhana) karena pengambilan anggota sampel dari populasi dilakukan secara acak tanpa memperhatikan strata yang ada dalam populasi itu (Sugiyono, 2010:118).

\section{F. Teknik Analisis}

Teknik analisis data menggunakan analisis faktor eksploratori yang merupakan suatu teknik statistik multivariat yang digunakan untuk mengurangi (mereduksi) dan meringkas semua variabel terikat dan saling berketergantungan. Hubungan antara satu indikator dengan indikator yang lain akan diuji untuk diidentifikasikan dimensi atau faktornya (Malhotra, 1996 dalam Ujianto dan Abdurrachman, 2004). 
Model analisis faktor secara umum:

$\mathrm{Xi}=\mathrm{AilF1}+\mathrm{Ai} 2 \mathrm{~F} 2+\mathrm{Ai} 3 \mathrm{~F} 3+. .+\mathrm{AimFm}+$ ViUi

Dimana:

$\mathrm{Xi}=$ standarisasi indikator ke-1

Aij =standarisasi koefisien regresi berganda indikator 1 pada faktor biasa j

F2 = faktor biasa

$\mathrm{Vi}=$ standarisasi koefisien regresi dari indikator 1 pada unik i

$\mathrm{Ui}=$ faktor unik untuk indikator 1

$\mathrm{m} \quad$ = banyaknya faktor biasa

Faktor-faktor yang unik tidak saling berkorelasi dan tidak berkorelasi dengan faktor biasa.Faktor-faktor biasa sendiri dapat dinyatakan sebagai kombinasi linear dari indikator yang diamati. Persamaannya sebagai berikut:

$F i=W i 1 X 1+W i 2 X 2+W i 3 X 3+\ldots+$ WikXik

Dimana :

$\mathrm{Fi}=$ estimasi faktor ke-i

Wil = bobot atau koefisiensi skor faktor

$\mathrm{K}=$ banyaknya indikator

\section{G. Uji Validitas dan Reliabilitas}

Kriteria valid adalah bila korelasi $r>$ 0. Jadi apabila korelasi antara butir dengan skor total <0,3 maka butir dalam instrument tersebut dinyatakan valid (Sugiyono,2010:126). Suatu skala pengukuran disebut valid apabila melakukan apa yang seharusnya dilakukan dan mengukur apa yang seharusnya diukur (Kuncoro, 2003:151).Sedangkan reliabilitas menurut Nazir (2003:133) adalah alat ukur mempunyai reliabilitas tinggi atau dapat dipercaya apabila alat ukur itu mantap atau stabil, dapat diandalkan dan dapat diramalkan. Keseluruhan indikator dianggap sudah cukup reliabel bilamana $a \geq 0$,6. Pengujian instrument penelitian dilakukan dengan instrumen komputer melalui program SPSS release 18 .

\section{H. Analisis Data}

Pada penelitian ini analisis faktor yang digunakan bertujuan untuk mengeksplorasi indikator-indikator baru yang membentuk suatu faktor.Model atau teknik analisis faktor, menggunakan Principal Component Analysis (PCA).Hasil perhitungan menurut Maholtra (1996:646) terdapat beberapa kunci statistic.

Barlett's test of sphericity, yaitu yang digunakan untuk menguji interdependensi antara butir-butir yang menjadi indikator suatu indikator atau faktor.Analisis ini bermaksud untuk mengetahui indikator yang tidak berkolerasi satu dengan yang lainnya (colinearity) dalam populasi.Apabila ternyata terbukti ada indikator yang berkorelasi maka salah satu dari indikator tersebut tidak perlu dianalisis.Sedangkan Keiser-Meyer Olkin (KMO) measure of sampling adequancy, adalah angka indeks untuk membandingkan antara besarnya koefisien korelasi observasi dengan besarnya koefisien korelasi parsial. Apabila nilai KMO kecil (kurang dari 0,5) menunjukkan bahwa korelasi antar indikator tidak dapat menjelaskan 
indikator lain dan analisis faktor tidak sesuai untuk diterapkan.

\section{Tabel 1.}

Kaiser-Meyer Olkin (KMO) Measure of Sampling Adequancy

\begin{tabular}{|c|c|c|}
\hline \multicolumn{2}{|c|}{$\begin{array}{r}\text { KMO Measure of Sampling } \\
\text { Adquency }\end{array}$} & 0,721 \\
\hline $\begin{array}{r}\text { Barlett's Test } \\
\text { of Sphericity }\end{array}$ & $\begin{array}{c}\text { Approx. Chi- } \\
\text { Square }\end{array}$ & 568,616 \\
\hline & Df & 190 \\
\hline & Sig. & 0,000 \\
\hline
\end{tabular}

Sumber : Hasil penelitian, 2014 (diolah)

Nilai Keiser-Meyer Olkin (KMO) measure of sampling adequancy hasil perhitungan adalah $0,721>0,5$ yang berarti bahwa korelasi antar indikator dapat menjelaskan indikator lain dan analisis faktor sesuai untuk dijadikan alat analisis.

Correlation matrix, yaitu matrik korelasi yang merupakan hasil korelasi antar butir yang menunjukkan koefisien korelasi (r) antara butir satu dengan butir yang lainnya, yang dapat atau tidak dimasukkan dalam analisis.Pada hasil analisis faktor dalam tabel anti image correlation.

Tabel 2.

\section{Nilai Korelasi Anti image}

\begin{tabular}{|c|c|c|c|c|c|}
\hline indikator & $\begin{array}{c}\text { Anti } \\
\text { image }\end{array}$ & hasil & indikator & $\begin{array}{c}\text { Anti } \\
\text { image }\end{array}$ & hasil \\
\hline X1 & 0,607 & diuji & X11 & 0,819 & diuji \\
\hline X2 & 0,608 & diuji & X12 & 0,697 & diuji \\
\hline X3 & 0,717 & diuji & X13 & 0,834 & diuji \\
\hline X4 & 0,682 & diuji & X14 & 0,580 & diuji \\
\hline X5 & 0,709 & diuji & X15 & 0,630 & diuji \\
\hline X6 & 0,617 & diuji & X16 & 0,815 & diuji \\
\hline X7 & 0,674 & diuji & X17 & 0,698 & diuji \\
\hline X8 & 0,749 & diuji & X18 & 0,607 & diuji \\
\hline X9 & 0,798 & diuji & X19 & 0,861 & diuji \\
\hline X10 & 0,817 & diuji & X20 & 0,802 & diuji \\
\hline
\end{tabular}

Sumber : Hasil penelitian, 2014 (diolah)

Communality, yaitu jumlah varians yang diberikan tiap-tiap butir dalam butir lain. Koefisien communality 50\%, maka harus dipertimbangkan besarnya muatan faktor.

Tabel 3. Nilai Communalities

\begin{tabular}{|c|c|c|c|}
\hline $\begin{array}{c}\text { indikato } \\
r\end{array}$ & $\begin{array}{c}\text { Extractio } \\
n\end{array}$ & $\begin{array}{c}\text { indikato } \\
r\end{array}$ & $\begin{array}{c}\text { Extractio } \\
n\end{array}$ \\
\hline $\mathrm{X} 1$ & 0,627 & $\mathrm{X} 11$ & 0,537 \\
\hline $\mathrm{X} 2$ & 0,737 & $\mathrm{X} 12$ & 0,701 \\
\hline $\mathrm{X} 3$ & 0,771 & $\mathrm{X} 13$ & 0,594 \\
\hline $\mathrm{X} 4$ & 0,568 & $\mathrm{X} 14$ & 0,734 \\
\hline $\mathrm{X} 5$ & 0,573 & $\mathrm{X} 15$ & 0,805 \\
\hline $\mathrm{X} 6$ & 0,586 & $\mathrm{X} 16$ & 0,505 \\
\hline $\mathrm{X} 7$ & 0,744 & $\mathrm{X} 17$ & 0,594 \\
\hline $\mathrm{X} 8$ & 0,579 & $\mathrm{X} 18$ & 0,499 \\
\hline $\mathrm{X} 9$ & 0,541 & $\mathrm{X} 19$ & 0,557 \\
\hline $\mathrm{X} 10$ & 0,554 & $\mathrm{X} 20$ & 0,541 \\
\hline
\end{tabular}

Sumber : Hasil penelitian, 2014 (diolah)

Hasil perhitungan pada Tabel 1.3 menunjukkan nilai korelasi tertinggi pada indikator ke 15 dengan nilai 0,805. Ini menunjukkan nilai korelasi indikator tersebut berkorelasi erat dengan faktor yang akan terbentuk. Sedangkan nilai korelasi terendah 0,499 pada pertanyaan ke 18 yang berarti indikator tersebut berkorelasi paling rendah dengan faktor yang akan terbentuk dan mempunyai nilai kurang dari 0,5.

Faktor yang mempunyai eigenvalue satu, yang dimasukkan dalam model, sedangkan yang nilainya kurang dari satu merupakan faktor yang tidak dimasukkan dalam model.Apabila eigenvalue lebih besar dari satu maka semakin representatif faktor tersebut mewakili indikator.

Tabel 4. 
Nilai Eigenvalue dan \% Variance Explained

\begin{tabular}{|c|c|c|c|c|c|c|}
\hline \multirow{2}{*}{ Component } & \multicolumn{3}{|c|}{ Initial Eigenvalues } & \multicolumn{3}{c|}{ Rotation Sums of Squared } \\
\cline { 2 - 7 } & Toadalings & $\begin{array}{c}\% \text { of } \\
\text { Variance }\end{array}$ & $\begin{array}{c}\text { Cumulative } \\
\%\end{array}$ & Total & $\begin{array}{c}\% \text { of } \\
\text { Variance }\end{array}$ & $\begin{array}{c}\text { Cumulative } \\
\%\end{array}$ \\
\hline 1 & 4,875 & 24,373 & 24,373 & 4,875 & 24,373 & 24,373 \\
\hline 2 & 2,122 & 10,612 & 34,984 & 2,122 & 10,612 & 34,984 \\
\hline 3 & 1,516 & 7,581 & 42,566 & 1,516 & 7,581 & 42,566 \\
\hline 4 & 1,441 & 7,206 & 49,772 & 1,441 & 7,206 & 49,772 \\
\hline 5 & 1,248 & 6,241 & 56,013 & 1,248 & 6,241 & 56,013 \\
\hline 6 & 1,145 & 5,724 & 61,737 & 1,145 & 5,724 & 61,737 \\
\hline
\end{tabular}

Sumber : Hasil penelitian, 2014 (diolah)

Percentage of variance, yaitu total dari varians explained aribut-atribut dari masing-masing faktor sebesar 61,737\%. Nilai ini lebih dari 50 \% sehingga faktor yang terbentuk dari proses analisis faktor dapat diterima.

Dari faktor matrix ini dapat dilihat pengaruh dari indikator terhadap faktor. Hasil perhitungan component matriks dapat dilihat pada Tabel 1.5 yang menunjukkan ada enam faktor yang terbentuk. Dalam komponen matriks yang dapat diinterprestasikan apabila mempunyai nilai loading faktor lebih dari 0,5 .

Tabel 5.

\section{Hasil Perhitungan Komponen Matriks}

\begin{tabular}{|l|r|r|r|r|r|r|}
\hline & \multicolumn{7}{|c|}{ Component } \\
\cline { 2 - 7 } & $\mathbf{1}$ & $\mathbf{2}$ & \multicolumn{1}{|c|}{$\mathbf{3}$} & \multicolumn{1}{|c|}{$\mathbf{4}$} & \multicolumn{1}{c|}{$\mathbf{5}$} & \multicolumn{1}{|c|}{$\mathbf{~}$} \\
\hline $\mathrm{X}_{1}$ & 0,262 & 0,475 & 0,255 & $-0,280$ & 0,433 & 0,046 \\
\hline $\mathrm{X}_{2}$ & 0,365 & 0,455 & $-0,169$ & $-0,340$ & 0,416 & 0,281 \\
\hline $\mathrm{X}_{3}$ & 0,636 & $-0,200$ & 0,375 & $-0,257$ & $-0,262$ & $-0,228$ \\
\hline $\mathrm{X}_{4}$ & 0,432 & 0,147 & 0,513 & 0,113 & $-0,271$ & 0,100 \\
\hline $\mathrm{X}_{5}$ & 0,526 & 0,190 & 0,457 & 0,127 & $-0,073$ & $-0,172$ \\
\hline $\mathrm{X}_{6}$ & 0,322 & 0,376 & 0,090 & $-0,450$ & $-0,167$ & 0,320 \\
\hline $\mathrm{X}_{7}$ & 0,530 & 0,537 & $-0,245$ & 0,242 & $-0,237$ & $-0,013$ \\
\hline $\mathrm{X}_{8}$ & 0,595 & 0,267 & 0,108 & 0,221 & 0,204 & 0,228 \\
\hline $\mathrm{X}_{9}$ & 0,581 & $-0,321$ & $-0,090$ & 0,173 & 0,194 & $-0,155$ \\
\hline $\mathrm{X}_{10}$ & 0,594 & $-0,225$ & $-0,206$ & $-0,326$ & 0,041 & 0,021 \\
\hline $\mathrm{X}_{11}$ & 0,599 & $-0,067$ & $-0,350$ & $-0,149$ & 0,111 & $-0,130$ \\
\hline $\mathrm{X}_{12}$ & 0,466 & $-0,447$ & $-0,180$ & 0,154 & $-0,308$ & 0,365 \\
\hline $\mathrm{X}_{13}$ & 0,656 & $-0,161$ & 0,194 & $-0,053$ & 0,136 & $-0,282$ \\
\hline $\mathrm{X}_{14}$ & 0,278 & 0,483 & $-0,159$ & 0,386 & $-0,047$ & $-0,497$ \\
\hline $\mathrm{X}_{15}$ & 0,123 & 0,225 & 0,122 & 0,658 & 0,404 & 0,358 \\
\hline $\mathrm{X}_{16}$ & 0,541 & $-0,165$ & $-0,093$ & $-0,021$ & 0,327 & $-0,262$ \\
\hline $\mathrm{X}_{17}$ & 0,479 & $-0,389$ & 0,376 & 0,019 & 0,218 & 0,154 \\
\hline $\mathrm{X}_{18}$ & 0,300 & $-0,488$ & $-0,015$ & 0,260 & 0,230 & 0,223 \\
\hline $\mathrm{X}_{19}$ & 0,599 & $-0,001$ & $-0,274$ & $-0,040$ & $-0,276$ & 0,213 \\
\hline $\mathrm{X}_{20}$ & 0,554 & 0,080 & $-0,471$ & 0,065 & $-0,026$ & $-0,029$ \\
\hline
\end{tabular}

Sumber : Hasil penelitian, 2014 (diolah)

Pada faktor pertama yang mempunyai nilai lebih dari 0,5 yaitu $X 3, X 5$, x8, X9, X10, X11, X13, X16, X19, X20. Sedangkan faktor kedua yang mempunyai nilai lebih dari 0,5 pada indikator X7. Sedangkan faktor ketiga yang mempunyai nilai lebih dari 0,5 pada indikator X4. Sedangkan pada faktor keempat yang mempunyai nilai lebih dari 0,5 pada indikator X15.

Tabel 6.

\section{Hasil Perhitungan Rotasi Faktor}

\begin{tabular}{|l|c|c|c|c|c|c|}
\multirow{2}{*}{} & \multicolumn{7}{|c|}{ Component } \\
\cline { 2 - 7 } & 1 & 2 & 3 & 4 & 5 & 6 \\
\hline $\mathrm{X}_{1}$ & 0,128 & 0,208 & $-0,230$ & 0,708 & 0,073 & 0,089 \\
\hline $\mathrm{X}_{2}$ & 0,164 & $-0,088$ & 0,157 & 0,813 & 0,075 & 0,105 \\
\hline $\mathrm{X}_{3}$ & 0,423 & 0,654 & 0,156 & 0,000 & $-0,080$ & $-0,366$ \\
\hline $\mathrm{X}_{4}$ & $-0,028$ & 0,732 & 0,141 & 0,062 & 0,027 & 0,082 \\
\hline $\mathrm{X}_{5}$ & 0,222 & 0,682 & $-0,024$ & 0,102 & 0,210 & 0,069 \\
\hline $\mathrm{X}_{6}$ & $-0,149$ & 0,276 & 0,314 & 0,581 & $-0,044$ & $-0,221$ \\
\hline $\mathrm{X}_{7}$ & 0,027 & 0,231 & 0,453 & 0,220 & 0,651 & 0,112 \\
\hline $\mathrm{X}_{8}$ & 0,058 & 0,487 & 0,447 & 0,179 & 0,228 & 0,232 \\
\hline $\mathrm{X}_{9}$ & 0,670 & 0,127 & 0,198 & $-0,110$ & 0,039 & 0,150 \\
\hline $\mathrm{X}_{10}$ & 0,535 & 0,053 & 0,399 & 0,208 & $-0,113$ & $-0,221$ \\
\hline $\mathrm{X}_{11}$ & 0,575 & $-0,042$ & 0,352 & 0,189 & 0,173 & $-0,123$ \\
\hline $\mathrm{X}_{12}$ & 0,223 & 0,138 & 0,705 & $-0,257$ & $-0,240$ & 0,105 \\
\hline $\mathrm{X}_{13}$ & 0,643 & 0,410 & 0,038 & 0,068 & 0,053 & $-0,061$ \\
\hline $\mathrm{X}_{14}$ & 0,149 & 0,136 & $-0,048$ & $-0,023$ & 0,827 & 0,086 \\
\hline $\mathrm{X}_{15}$ & $-0,016$ & 0,094 & $-0,006$ & 0,101 & 0,117 & 0,879 \\
\hline $\mathrm{X}_{16}$ & 0,692 & 0,064 & 0,039 & 0,102 & 0,099 & 0,029 \\
\hline $\mathrm{X}_{17}$ & 0,466 & 0,405 & 0,068 & 0,021 & $-0,403$ & 0,215 \\
\hline $\mathrm{X}_{18}$ & 0,414 & 0,014 & 0,215 & $-0,193$ & $-0,316$ & 0,379 \\
\hline $\mathrm{X}_{19}$ & 0,214 & 0,158 & 0,677 & 0,115 & 0,107 & $-0,060$ \\
\hline $\mathrm{X}_{20}$ & 0,385 & $-0,078$ & 0,500 & 0,124 & 0,347 & 0,016 \\
\hline
\end{tabular}

Sumber : Hasil penelitian, 2014 (diolah)

Pada tabel 1.6 menunjukkan ada 6 faktor yang terbentuk. Dalam rotasi faktor yang dapat diinterprestasikan adalah apabila mempunyai nilai loading faktor lebih dari 0,5.

1. Faktor pertama yang mempunyai nilai lebih dari 0,5 pada indikator X9, X10, $\mathrm{X} 11, \mathrm{X} 13$ dan X16.

2. Faktor kedua yang mempunyai nilai lebih dari 0,5 pada indikator X3, X4, X5.

3. Faktor ketiga yang mempunyai nilai lebih dari 0,5 pada indikator X12, X19, X20. 
4. Faktor keempat yang mempunyai nilai lebih dari 0,5 pada indikator X1, X2 dan X6.

5. Faktor kelima yang mempunyai nilai lebih dari 0,5 pada indikator $X 7$ dan $\mathrm{X} 14$.

6. Faktor keenam yang mempunyai nilai lebih dari 0,5 pada indikator X15.

Faktor pertama yang mempunyai nilai lebih dari 0,5 pada indikator $\mathrm{X9}, \mathrm{X10}$, $X 11, X 13$,dan $X 16$. Nilai loading factor terendah terletak pada indikator $X 10$ yaitu kurang mendapat informasi dengan jelas tentang produk-produk Bank Syariah.Nilai loading factor terendah terletak pada indikator ke-10 (X10) yaitu kurang mendapat informasi dengan jelas tentang produk-produk Bank Syariah. Nilai loading faktor tertinggi terletak pada indikator ke16 (X16) dengan nilai loading 0,692. Indikator tersebut mengenai istilah produk pada layanan perbankan di Bank Syariah dengan nama Islami sehingga konsumen sulit untuk memahaminya.Berdasarkan indikator tersebut maka disebut atau dinamai dengan faktor citra merek perbankan syariah.

Faktor kedua yang mempunyai nilai lebih dari 0,5 pada indikator $\mathrm{X} 3, \mathrm{X} 4$, dan X5. Nilai loading factor terendah terletak pada indikator ketiga X3 yaitu merasa sudah puas menjadi nasabah bank konvensional sehingga tidak perlu menjadi nasabah Bank Syariah.Nilai loading factor terendah terletak pada indikator ketiga (X3) yaitu merasa sudah puas menjadi nasabah bank konvensional sehingga tidak perlu menjadi nasabah Bank Syariah.Nilai loading faktor tertinggi terletak pada indikator ke-4 (X4) dengan nilai loading 0,732.Indikator tersebut mengenai adanya pengetahuan bahwa bunga adalah riba dan diharamkan, tetapi selama bunga tidak melebihi tingkat inflasi $10 \%$ maka bunga bank tidak disebut riba.Berdasarkan indikator tersebut makadisebut atau dinamai dengan faktor product knowledge.

Faktor ketiga yang mempunyai nilai lebih dari 0,5 pada indikator $\mathrm{X} 12, \mathrm{X} 19$, dan X20. Nilai loading factor terendah terletak pada indikator X20 yaitu produk pada layanan perbankan syariah masih kurang variatif untuk memenuhi kebutuhan konsumen.Nilai loading factor terendah terletak pada indikator ke-20 (X20) yaitu produk pada layanan perbankan syariah masih kurang variatif untuk memenuhi kebutuhan konsumen. Nilai loading faktor tertinggi terletak pada indikator ke-12 (X12) dengan nilai loading 0,705.Indikator tersebut mengenai Keuntungan bagi hasil Bank Syariah dianggap kurang menguntungkan dibandingkan bunga bank konvensional.Berdasarkan indikator tersebut maka disebut atau dinamai dengan faktor keuntungan bagi hasil.

Faktor keempat yang mempunyai nilai lebih dari 0,5 pada indikatorX1, X2, dan X6. Nilai loading factor terendah terletak pada indikator X6 yaitu lokasi bank jauh dijangkau dari kampus.Nilai loading factor terendah terletak pada indikator ke-6 (X6) yaitu lokasi bank jauh 
dijangkau dari kampus. Nilai loading faktor tertinggi terletak pada indikator ke2 (X2) dengan nilai loading 0,813.Indikator tersebut mengenai Kantor cabang Bank Syariah masih sedikit sehingga untuk menjangkaunya sulit/jauh dari tempat tinggal.Berdasarkan indikator tersebut maka disebut atau dinamai dengan

\section{faktor lokasi.}

Faktor kelima yang mempunyai nilai lebih dari 0,5 pada indikator $X 7$, danX14. Nilai loading factor terendah terletak pada indikator $X 7$ yaitu kebutuhan untuk transaksi jual-beli online menggunakan rekening bank konvensional karena sebagian besar customer/seller juga menggunakan rekening bank konvensional.Nilai loading factor terendah terletak pada indikator ke-7 (X7) yaitu kebutuhan untuk transaksi jual-beli online menggunakan rekening bank konvensional karena sebagian besar customer/seller juga menggunakan rekening bank konvensional. Nilai loading faktor tertinggi terletak pada indikator ke14 (X14) dengan nilai loading 0,827 .Indikator tersebut mengenai terpaksa membuka rekening bank konvensional karena suatu kebutuhan yang mengharuskan memiliki rekening bank konvensional. Responden sebagian besar memilih menjadi nasabah bank konvensional karena beberapa kebutuhan yang mengharuskan memiliki rekening bank konvensional tertentu seperti kebutuhan menerima dana beasiswa PPA/BBM yang diharuskan membuka rekening Bank Mandiri, beberapa mahasiswa yang memilih mengisi waktu luang dengan bekerja diharuskan memiliki rekening bank konvensional tertentu berdasarkan kebijakan dari perusahaan tempat responden bekerja untuk menerima pendapatan tiap bulan.Berdasarkan indikator tersebut maka disebut atau dinamai dengan faktor spurious loyalty.Faktor suporious loyalty adalah keadaan dimana nasabah tetap menggunakan layanan perbankan konvensional karena nasabah memiliki kebutuhan yang memaksa dan beberapa keadaan yang membuat nasabah tidak bisa lepas untuk menggunakan layanan perbankan konvensional.

Faktor keenam yang mempunyai nilai lebih dari 0,5 pada indikator pernah berpengalaman mendapatkan pelayanan di Bank Syariah tetapi kurang memuaskan (X15) dengan nilai loading factor sebesar 0,879. Indikator tersebut mengenai pernah berpengalaman mendapatkan pelayanan di Bank Syariah tetapi kurang memuaskan.Responden mengaku pernah mendapatkan pengalaman kurang memuaskan ketika hendak mengirimkan sejumlah vang kepada saudara atau rekan (penerima) yang merupakan nasabah Bank Syariah yaitu berupa ketidaktepatan waktu nasabah menerima uang tersebut dari batas waktu yang telah dijanjikan bank kepada pengirim.Berdasarkan indikator tersebut maka disebut atau dinamai dengan faktor pengalaman pelayanan. 
Tabel 7.

\section{Hasil Uji Validitas dan Reliabilitas}

Konfirmasi Hasil Analisis Faktor

\begin{tabular}{|l|c|c|c|c|}
\hline \multicolumn{1}{|c|}{ Faktor } & Indikator & $\begin{array}{c}\text { Corrected Item- } \\
\text { Total Correlation }\end{array}$ & $\begin{array}{c}\text { Alpha } \\
\text { Cronbach }\end{array}$ & Keterangan \\
\hline $\begin{array}{l}\text { 1(faktor citra merek } \\
\text { perbankan syariah) }\end{array}$ & $\mathrm{X}_{9}$ & 0.538 & 0,750 & Reliabel \\
\hline & $\mathrm{X}_{10}$ & 0.514 & & \\
\hline & $\mathrm{X}_{11}$ & 0.513 & & \\
\hline & $\mathrm{X}_{13}$ & 0.506 & & \\
\hline $\begin{array}{l}\text { 2(faktor product } \\
\text { knowledge) }\end{array}$ & $\mathrm{X}_{16}$ & 0.502 & & \\
\hline & $\mathrm{X}_{3}$ & 0.528 & 0,665 & Reliabel \\
\hline & $\mathrm{X}_{4}$ & 0.434 & & \\
\hline $\begin{array}{l}3 \text { (faktorkeuntungan } \\
\text { bagihasil) }\end{array}$ & $\mathrm{X}_{5}$ & 0.470 & & \\
\hline & $\mathrm{X}_{12}$ & 0.366 & 0,589 & $\begin{array}{c}\text { Tidak } \\
\text { Reliabel }\end{array}$ \\
\hline & $\mathrm{X}_{19}$ & 0.469 & & \\
\hline 4(faktorlokasi) & $\mathrm{X}_{20}$ & 0.355 & & \\
\hline & $\mathrm{X}_{1}$ & 0.383 & 0,588 & $\begin{array}{c}\text { Ridak } \\
\text { Reliabel }\end{array}$ \\
\hline & $\mathrm{X}_{2}$ & 0.481 & & \\
\hline $\begin{array}{l}\text { 5(faktor suporious } \\
\text { loyalty) }\end{array}$ & $\mathrm{X}_{6}$ & 0.314 & & \\
\hline & $\mathrm{X}_{7}$ & 0.486 & 0,654 & Reliabel \\
\hline $\begin{array}{l}\text { 6(faktor pengalaman } \\
\text { pelayanan) }\end{array}$ & $\mathrm{X}_{14}$ & 0.486 & & \\
\hline & $\mathrm{X}_{15}$ & - & - & Reliabel \\
\hline
\end{tabular}

Sumber : Hasil penelitian, 2014 (diolah)

Dijelaskan hasil uji validitas dan reliabilitas konfirmasi hasil analisis faktor, diketahui bahwa faktor ketiga dan faktor keempat tidak reliabel karena memiliki nilai Cronbach Alpha kurang dari 0,6 sehingga faktor yang dapat mempengaruhi keputusan Mahasiswa S1 Ekonomi Islam Fakultas Ekonomi dan Bisnis Universitas Airlangga yaitu, faktor citra merek perbankan syariah, faktor product knowledge, faktor spurious loyalty, dan faktor pengalaman pelayanan. Terdapat dua faktor yang tidak reliabel yaitu, faktor keuntungan bagi hasil dan faktor lokasi.Alasan kedua faktor tersebut dinyatakan tidak reliabel, karena hasil pengukuran atau pengamatan secara fakta atau pada kenyataannya tidak menunjukkan konsistensi ketika diamati dalam waktu yang berlainan. Menurut Sugiono (2005), reliabilitas adalah serangkaian pengukuran atau serangkaian alat ukur yang memiliki konsistensi bila pengukuran yang dilakukan secara berulang-ulang. Hasil pengukuran harus reliabel dalam artian harus memiliki tingkat konsistensi dan kemantapan.

\section{PEMBAHASAN}

\section{A. Faktor citra merek perbankan syariah}

Faktor citra merek perbankan syariah merupakan faktor yang dipertimbangkan oleh mahasiswa S1 Ekonomi Islam Fakultas Ekonomi dan Bisnis di Universitas Airlangga sehingga belum memutuskan untuk menjadi nasabah Bank Syariah. Kurangnya informasi tentang gambaran jelas produk-produk perbankan syariah, dan kurangnya pemahaman dari istilah-istilah Islami produk perbankan syariah, serta adanya anggapan bahwa Bank Syariah kurang bonafit menjadikan mahasiswa belum memutuskan untuk menjadi nasabah Bank Syariah. Selain itu, adanya anggapan bahwa kurang leluasa ketika berinteraksi di dalam lingkungan Bank Syariah karena image Bank Syariah adalah tempat orang-orang fanatik.Kurangnya promo yang dilakukan Bank Syariah untuk menarik calon nasabah juga menjadi salah satu sebab bagi mahasiswa S1 Ekonomi Islam Fakultas Ekonomi dan Bisnis Universitas Airlangga belum memilih menjadi nasabah Bank Syariah.

Hal ini sesuai dengan Asmaran (1992:1-3) yang mengatakan bahwa perilaku konsumen berasal dari akhlak yang berarti budi pekerti, tingkah laku, 
dantabiat.Menurut Ratnawaty (2008), informasi memiliki peranan penting untuk mendukung suatu persepsi dan citra suatu perusahaan, baik itu dari media elektronik, media cetak, teman, keluarga, maupun informasi langsung dari pihak perusahaan. Dijelaskan dalam Al-Quran surat AlBaqarah (2) ayat 276:

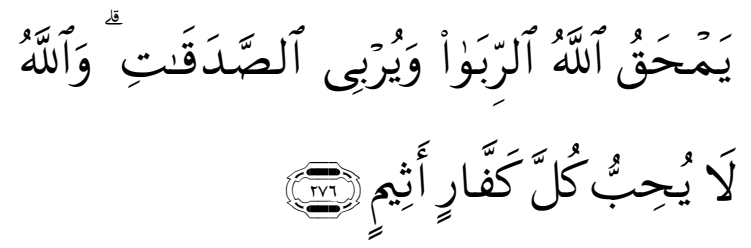

Yam ḥakullahū-ribawā wa yur bī-șadaqati. Wallahu lā yuhibbu kulla kaffā rin asím.

Artinya: "Allah memusnahkan riba dan menyuburkan sedekah.Dan Allah tidak menyukai setiap orang yang tetap dalam kekhafiran dan selalu berbuat dosa."(Departemen Agama Rl, $2011: 46$ ).

\section{B. Faktor product knowledge}

Faktor product knowledge merupakan faktor yang dipertimbangkan oleh mahasiswa S1 Ekonomi Islam Fakultas Ekonomi dan Bisnis di Universitas Airlangga sehingga belum memutuskan untuk menjadi nasabah Bank Syariah. Merasa sudah puas menjadi nasabah bank konvensional sehingga tidak perlu menjadi nasabah Bank Syariah serta adanya pendapat yang menjelaskan bahwa dengan membuka rekening baru di Bank Syariah maka akan menambah beban administrasi bulanan yang berupa potongan biaya ATM, karena sebelumnya sudah memiliki rekening di bank konvensional. Selain itu, adanya anggapan bahwa bunga adalah riba dan diharamkan, tetapi selama bunga tersebut tidak melebihi tingkat inflasi $10 \%$ maka bunga tetap dalam batas wajar dan tidak disebut riba'.

Pada hasil penelitian yang dilakukan Ratnawaty (2008) tentang perilaku konsumen pada perbankan syariah menjelaskan bahwa, faktor pengetahuan tentang produk (product knowledge) merupakan salah satu faktor yang memiliki potensi tinggi dalam membentuk suatu keputusan konsumen sebelum memutuskan memilih suatu produk perbankan.Dijelaskan dalam AlQuran surat Al-Baqarah (2) ayat 278:

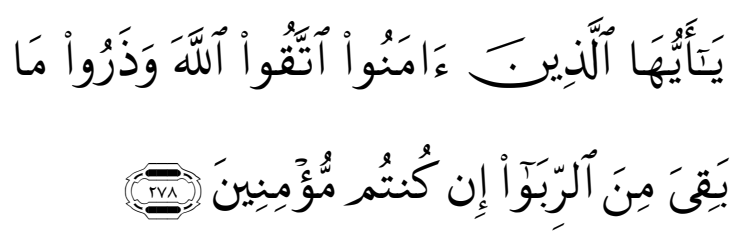

Yā ayyuhallażī na āmanu-takullāha wa żarū mā bakiya mina-ribā wā inkuntum mu"minīn.

Artinya: "Hai orang-orang beriman, bertakwalah kepada Allah dan tinggalkan sisa riba (yang belum dipungut) jika kamu orang-orang beriman."(Departemen Agama RI, 2011:46).

\section{Faktor spurious loyalty}

Faktor spurious loyalty merupakan faktor yang dipertimbangkan oleh mahasiswa S1 Ekonomi Islam Fakultas Ekonomi dan Bisnis di Universitas Airlangga sehingga belum memutuskan untuk menjadi nasabah Bank Syariah. Adanya kebutuhan yang memaksa nasabah tetap menggunakan layanan perbankan 
konvensional dan beberapa keadaan yang membuat nasabah tidak bisa lepas untuk menggunakan layanan perbankan konvensional merupakan salah satu faktor yang menjadi penyebab mahasiswa S1 Ekonomi Islam Fakultas Ekonomi dan Bisnis Uniersitas Airlangga belum memutuskan menjadi nasabah Bank Syariah. Banyaknya kebutuhan mahasiswa dalam halmenyimpan vang pada rekening bank konvensional tertentu membuat mahasiswa memilih menjadi nasabah tetap bank konvensional, seperti halnya mahasiswa yang bekerja dan diharuskan memiliki rekening bank konvensional tertentu untuk penerimaan gaji setiap bulannya, mahasiswa yang mendapatkan beasiswa diharuskan memiliki rekening bank konvensional tertentu yang sudah ditentukan oleh pihak pemberi beasiswa tersebut, atau mahasiswa mengikuti pilihan kelvarga (orang tua) dalam membuka rekening bank konvensional tertentu supaya lebih praktis dan tidak dikenakan potongan biaya ketika melakukan transaksi (transfer vang). Selain itu, kebutuhan mahasiswa yang gemar melakukan transaksi jual-beli online tidak jarang menggunakan rekening yang sebagian besar digunakan oleh pembeli/penjualnya, dengan tujuan untuk menghindari adanya biaya administrasi berupa charge ketika melakukan transaksi pembayaran.

Hal tersebut sejalan dengan hasil penelitian yang dilakukan oleh Cannon dan Broyles (2006) yang menyatakan bahwa faktor yang mempunyai pengaruh paling tinggi terhadap keputusan mahasiswa dalam memilih jasa perbankan adalah peran keluarga dan potensi pendapatan.Dijelaskan dalam AlQuran surat Al-Baqarah (2) ayat 279:

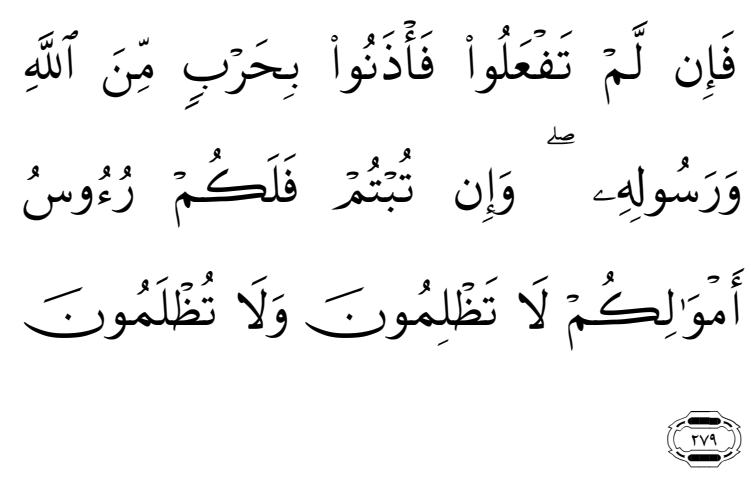

Fa illam taf"alū fa ażanū bikharbimminallāhi warosūlih.wa intubtum falakum ru"ūsu amwā likum lā taẓlimūna wa lā tužlamūn.

Artinya: "Maka jika kamu tidak mengerjakan (meninggalkan riba) maka ketahuilah, bahwa Allah dan Rasul-Nya akan memerangimu.Dan jika kamu bertaubat (dari pengambilan riba) maka bagimu pokok hartamu, kamu tidak menganiaya dan tidak pula dianaiaya."(Departemen Agama RI, 2011:46).

\section{Faktor pengalaman pelayanan}

Faktor pengalaman pelayanan merupakan faktor yang dipertimbangkan oleh mahasiswa S1 Ekonomi Islam Fakultas Ekonomi dan Bisnis di Universitas Airlangga sehingga belum memutuskan untuk menjadi nasabah Bank Syariah.Pengalaman mendapatkan pelayanan yang kurang memuaskan via teller, berupa ketidaktepatan waktu dalam penerimaan vang dari non- 
nasabah selaku penyetor yang mengirimkan sejumlah uang kepada penerima selaku nasabah Bank Syariah.Penerima selaku nasabah Bank Syariah mengaku mengalami keterlambatan dalam menerima vang dari waktu yang telah dijanjikan kepada penyetor yang merupakan bukan nasabah Bank Syariah.

$$
\text { Ratnawaty (2008) menjelaskan }
$$

bahwa, suatu perusahaan dikatakan unggul jika pelayanan yang diberikan memiliki keprofesionalitasan dalam bekerja.Selain itu, hasil penelitiannya juga mengungkapkan bahwa, pelayanan yang cepat, mudah, dantepat waktu merupakan salah satu faktor yang dipertimbangkan konsumen dalam memilih jasa perbankan.

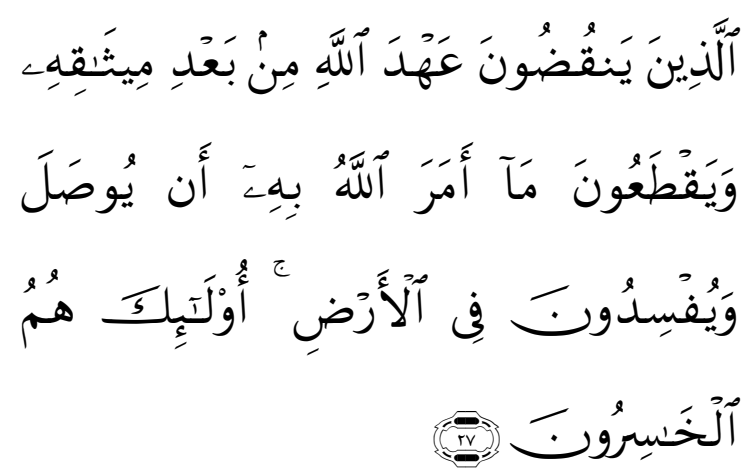

Allażina yankuḍūna "ahdallahi min-ba"di miśākihī.Wa yakța "Ūna mā amarallahu bihi anyū șala wa yufsidūna fil-arḍi. ulāika humul-hāsirūn.

Artinya: "orang-orang yang melanggar perjanjian Allah sesudah perjanjian itu teguh, dan memutuskan apa yang diperintahkan Allah untuk menghubungkannya, dan membuat kerusakan di muka bumi. Mereka itulah orang-orang yang rugi."(Departemen Agama Rl, 2011:45).

\section{SIMPULAN}

1. Faktor yang mempengaruhi keputusan Mahasiswa S1 Ekonomi Islam Fakultas Ekonomi dan Bisnis Universitas Airlangga Belum Menjadi Nasabah Bank Syariah terbentuk sebanyak empat faktor. Faktor yang terbentuk dinamai dengan faktor citra merek perbankan syariah, faktor product knowledge, faktor spurious loyalty, dan faktor pengalaman pelayanan.

2. Faktor dengan nilai loading tertinggi dari keempat faktor yang terbentuk adalah faktor pengalaman pelayanan, yang didapat dari hasil perhitungan rotasi faktor dengan loading tertinggi 0,879 yaitu pada indikator $\times 15$ mengenai pernah bepengalaman mendapatkan pelayanan di Bank Syariah tetapi kurang memuaskan. Hal ini menunjukkan bahwa setiap indikator dari semua faktor yang terbentuk dari keputusan mahasiswa S1 Ekonomi Islam Fakultas Ekonomi dan Bisnis Universitas Airlangga secara tidak disadari selalu memperhatikan aspek pelayanan saat memilih menjadi nasabah Bank Syariah.

\section{DAFTAR PUSTAKA}

Alamsyah, Halim. 2012, Perkembangan dan Prospek Perbankan Syariah Indonesia. IAEI.

Anshori Muslich dan Sri Iswati. 2009. Buku Ajar Metodologi Penelitian Kuantitatif. Surabaya: Pusat 
Penerbitan dan Percetakan UNAIR (AUP).

Antonio, Muhammad Syafii. 2001, Bank Syariah Dari Teori ke Praktek.

Gema Insani Press bekerja sama dengan Yayasan Tazkia Cendekia.

Departemen Agama RI. 2011. Al-Qur'an .

Gitosudarmo, Indriyo. 2004. Manajemen Pemasaran. Edisi Pertama Cetakan Keenam.BPFE-Yogyakarta.

Kotler, Philip dan AB. Susanto.2001. Manajemen Pemasaran Indonesia. Buku 2.Salemba empat. Jakarta.

-------, John Bowen and James Makens. 2002. Pemasaran Perhotelan dan Kepariwisataan.Edisi 2. Jakarta: PT Prenhallindo.

2004. Prinsip-prinsip Pemasaran Jilid

II. Jakarta: Erlangga.

-------, dan Kevin Lane Keller. 2009. Manajemen Pemasaran. Edisi 14. Jakarta: Erlangga.

Malhotra, Naresh K. 2010. Riset pemasaran: Pendekatan Terapan. Jilid 1. Jakarta: PT. Indeks.

Ratnasari, Ririn Tri. 2012. Konsep Dasar Syariah Marketing.Slide kuliah Manajemen Pemasaran Syariah. Pertemuan 1.Departemen Ekonomi Islam Fakultas Ekonomi dan Bisnis Universitas Airlangga.

-------. 2012. Manajemen Pemasaran Islam. Modul 1. Surabaya: Departemen Ekonomi Syariah Fakultas Ekonomi dan Bisnis Universitas Airlangga. dan Nisful Laila. 2012. Measuring Customer Service Quality Based on Fatanah Implementation. Proceedings of 2nd Global Islamic Marketing Conference

(GIMC). Abu Dhabi.

Solomon, M.R. 1999. Consumer Behaviour : Buying, Having, and Being, 4th Edition. New Jersey 07548; Prentice Hall.

Sugiyono.2010. Metode Penelitian

Kuantitatif Kualitatif. Bandung:

Alfabeta.

Sutisna.2001. Perilaku Konsumen dan Komunikasi Pemasaran. Bandung: PT. Remaja Rosdakarya.

Wibowo, Edy dan Untung Hendy Widodo. 2005. Mengapa Memilih Bank Syariah?. Bogor: Galia Indonesia. 